\title{
固定式中空円筒構造物の地震流力弾性応答への構造物一海水間隙の影響 EFFECT OF STRUCTURE-ICE GAP ON HYDROELASTIC RESPONSE OF FIXED HOLLOW CYLINDRICAL STRUCTURES DURING EARTHQUAKES
}

\author{
濱本卓司*, 井上昌士**, 大西弘亮*** \\ Takuji HAMAMOTO, Masashi INOUE and Hiroaki OONISHI
}

\begin{abstract}
The effect of pressure dissipation due to structure-ice gap on the hydroelastic response of fixed hollow cylindrical structures during earthquakes in ice-covered seas is investigated. The elastic shell theory is used for structures, whereas the potential flow theory is applied to fluid domain. The sea ice is idealized as the semi-infinite rigid boundary that is connected to the annular free surface between structure and sea ice. The hydrodynamic pressure is obtained in closed form by domain division method. Wet mode properties in beam mode of hollow cylindrical structures are evaluated by Rayleigh-Ritz method. The mode superposition approach is used to calculate the hydrodynamic pressure distribution and earthquake response against horizontal ground motion. Numerical examples are presented to illustrate the changes in hydrodynamic pressures and earthquake responses due to the width of structure-ice gap.
\end{abstract}

Keywords : Sea ice, Earthquake response, Structure-ice gap, Hydroelasticity, Domain division method, Circular cylindrical shell 海水，地震応答，構造物一海水間隙，流力弾性，領域分割法，円筒シェル

\section{1. 序}

氷海域に建設される構造物の耐震安全性を確保するには，地震時 に構造物周辺の海水が構造物に与える影響を定量的に把握すること が必要である。海氷が構造物に与える影響には，一般にばね効果や 質量効果として集約的にモデル化される構造物と海氷の相互作用効 果 ${ }^{1,2)}$ と海水が海面を覆うことにより動水圧を閉じ込めて増加させ る地震荷重の増幅効果 ${ }^{3,4}$ がある。オホーツク海のような一年氷の水 海域は氷が薄いため, 地震力が作用すると比較的早い段階で構造物 近傍の海水が破壊し，構造物と海水の相互作用効果は消失する。一 方, 海水が構造物周辺の海域を覆っていると, 地震動により水厚に は関わらず動水圧は増幅される。このような場合，地震荷重の増幅 効果は構造物と海氷の相互作用効果に比へて支配的になる。しかし， 実際には，構造物近傍の海水が破壞して構造物一海水間隙ができる ため, 海水による閉じ込め効果とは逆に間隙による消散効果も生じ ている。

著者らは，海面の全領域が氷盤に覆われている場合と部分的に覆 われている場合について，固定式中空円筒構造物に作用する動水圧 の増幅効果とその流力弾性応答への影響を数理モデルにより定量的

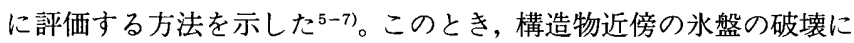
よる動水圧の消散効果はこれが小さいものとして無視した。しかし 水海水槽での実験結果に基づき, Kobayashi·Kawaguchi ${ }^{8}$ 'は構造物 一海水間隙の存在による動水圧の消散効果は無視できない場合があ ることを指摘している。一方これまでに構造物一海水間隙による
動水圧およびその荷重効果の変化を理論的に扱った研究はない。 本研究では, 構造物一海水間吵による動水圧の消散効果が氷海構 造物の地震応答挙動に与える影響を定量的に検討するために, 構造 物一海水間隙が存在する場合の固定式中空円筒構造物の地震流力弾 性解析を数理モデルにより定式化する。内筒構造物には弾性シェル 理論, 海水には線形ポテンシャル理論を適用する。氷盤は, 構造物 周囲の円環状の自由表面境界を隔てて半無限に広がる剛体境界とし て扱う。海面で自由表面境界と剛体境界が混在する混合境界値問題 に領域分割法を適用し，構造物に作用する動水圧を解析的に導く。 既報》と同様に, レーリー・リッツ法によりウェットモード特性を評 価し，モード合成法により水平地震動に対する動水圧分布と流力弾 性応答を求める。数值例題により，構造物一海水間隙の幅による動 水圧分布の変化を明らかにするとともに，それがウェットモード特 性と地震時の流力弾性応答に与える影響を検討する。

\section{2. 解析モデルと仮定}

構造物一海水間隙を介して海水に取り巻かれた固定式中空円筒構 造物を Fig. 1 に示す。構造物の高さを $l$, 半径を $a$, 厚さを $h$, 設置 水深を $d$ とする。構造物一海水間隙による動水圧の消散効果を検討 するという観点から, 間隙を構造物に隣接する幅 $b-a$ の円環状の 自由表面とし，その外側は無限に結水しているものと考える。地震 動として海底面の水平動を考之, 地盤変位を $U_{g}$, 構造物の面外弾性 変形を $w$ とする。

\footnotetext{
* 武蔵工業大学工学部建築学科 教授 · 工博

** 日本設計 修士 (工学)

*** 清水建設 修士(工学)
}

Prof., Dept. of Architecture, Musashi Institute of Technology, Dr. Eng. Nihon Sekkei, M. Eng.

Shimizu Corp., M. Eng. 
本研究では以下の仮定を導入する。

1）構造物の地震応答は線形振動の範囲内である。

2 ）構造物の応力一Uずみ関係は線形シェル理論に従う。

3 ）海水は構造物周辺の円環状の自由表面を介して半無限に広がる 剛体とみなすことができる。

4 ）海水は非粘性・非圧縮性・渦なしである。

5 ）水樑は一定で海水は水平方向に無限に広がっている。

6 ）海底は剛であり，海底地盤との相互作用は無視できる。

7 ) 地震動は水平成分のみを考之, その定常部の加速度パワースペ

クトルは修正金井・田治見式で与えられる。

\section{3. 地震荷重}

水平地震動を受けると中空円筒構造物は水平剛体運動と面内およ び面外の弾性変形で応答する。海底が剛であれば励起される弾性変 形は梁モード(円周方向フーリエ波数 $n=1$ )のみである。このとき 構造物には水平剛体運動による構造物の慣性力と水平剛体運動によ り生じる動水圧成分および面外弾性変形により生じる動水圧成分が 作用する。

構造物の慣性力と海水の動水圧の和が構造物に作用する地震力で ある。このうち, 動水圧は海面を覆う海水の閉じ込好効果と構造物 一海水間隙の消散効果の影響を同時に受ける。構造物一海水間隙の 幅 $b 一 a$ が 0 のとき，海面は全領域で剛体境界となり動水圧の閉じ 込効果は最大となる。構造物一海水間隙の幅 $b$ - $a$ が大きくなる と消散効果により動水圧は徐々に減少し, 無限大で全領域が自由表 面境界のときの動水圧に収束する。構造物一海水間隙の幅は動水圧 の大きさだけでなく分布形にも影響を与える。

\section{4. 動水圧の誘導}

水平地震動を受ける中空円筒構造物に作用する動水圧をポテン シャル流れ理論により求める。Fig. 2 に示すように, 構造物周辺に構 造物一海水間隙としての自由表面があり, その周囲を海氷が無限に 広がる状態を考える。このとき，海面には剛体境界と自由表面境界

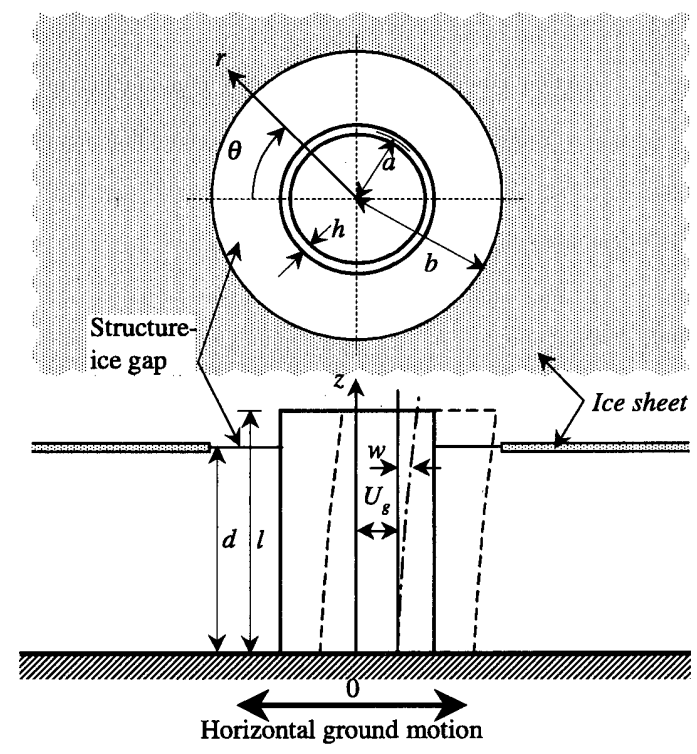

Fig. 1 Analytical model of hollow cylindrical structure subjected to horizontal ground motion in ice-covered seas
が同時に存在している。この混合境界值問題の解を領域分割法によ り以下に解析的に導く。

海水領域の速度ポテンシャルを以下のように表す。

$$
\Phi(r, \theta, z, t)=\phi(r, \theta, z) \exp (i \sigma t)
$$

ここに, $\phi(r, \theta, z)$ は速度ポテンシャルの空間項, $\exp (i \sigma t)$ は時 間項， $i=\sqrt{-1}, \sigma$ は円振動数， $t$ は時間である。

構造物一海水間隙を表す自由表面境界の下部領域の速度ポテン シャルの空間項 $\phi_{f}$ は以下の境界值問題を満足する。

$$
\begin{array}{ll}
\nabla^{2} \phi_{f}=0 & : 0 \leq z \leq d, \\
\frac{\partial \phi_{f}}{\partial z}-\frac{\sigma^{2}}{g} \phi_{f}=0 & : z=d, \\
\frac{\partial \phi_{f}}{\partial z}=0 & : z=0, \\
\frac{\partial \phi_{f}}{\partial r}=\dot{W} & : r=a .
\end{array}
$$

ここに, $W=U_{g}+w$ は構造物の面外変位, $\cdot=d / d t$ である。式(2a) は非粘性, 非圧縮性, 渦なしの流体場を支配するラプラス方程式, 式(2b)は海面における自由表面境界条件, 式(2c)は海底面における剛 体境界条件，式(2d)は構造物と海水の運動の連続条件である。

海水を表す剛体境界の下部領域の速度ポテンシャルの空間項 $\phi_{i}$ は以下の境界値問題を満足する。

$$
\begin{array}{ll}
\nabla^{2} \phi_{i}=0 & : 0 \leq z \leq d, \\
\frac{\partial \phi_{i}}{\partial z}=0 & : z=d, \\
\frac{\partial \phi_{i}}{\partial z}=0 & : z=0, \\
\phi_{i} \rightarrow 0 & : r \rightarrow \infty,
\end{array}
$$

ここに, 式(3b)は氷海面の剛体境界条件, 式(3d)は遠方での減衰条件 である。

式(2a-c)を満足する自由表面境界の下部領域の速度ポテンシャル の空間項 $\phi_{f}$ は次式で与えられる。

$$
\begin{aligned}
\phi_{f}= & \sum_{n=0}^{\infty}\left[\left\{B_{n 0} \frac{J_{n}(k r)}{J_{n}(k b)}+C_{n 0} \frac{Y_{n}(k r)}{Y_{n}(k b)}\right\} \cosh k z\right. \\
& \left.+\sum_{l=1}^{\infty}\left\{D_{n l} \frac{K_{n}\left(k_{l} r\right)}{K_{n}\left(k_{l} b\right)}+E_{n l} \frac{I_{n}\left(k_{l} r\right)}{I_{n}\left(k_{l} b\right)}\right\} \cos k_{l} z\right] \cos n \theta,
\end{aligned}
$$

ここに, $J_{n}(x)$ は $n$ 位の第 1 種べッセル関数, $Y_{n}(x)$ は $n$ 位の 第 2 種ベッセル関数, $I_{n}(x)$ は $n$ 位の第 1 種変形ベッセル関数, $K_{n}$ $(x)$ は $n$ 位の第 2 種変形ベッセル関数, $B_{n 0}, C_{n 0}, D_{n l}, E_{n l}$ は未定 係数, $k$ と $k_{l}$ は次式の超越方程式を満足する波数である。 $\sigma^{2}=k g \tanh k d=-k_{l} g \tan k_{l} d$.

(5)

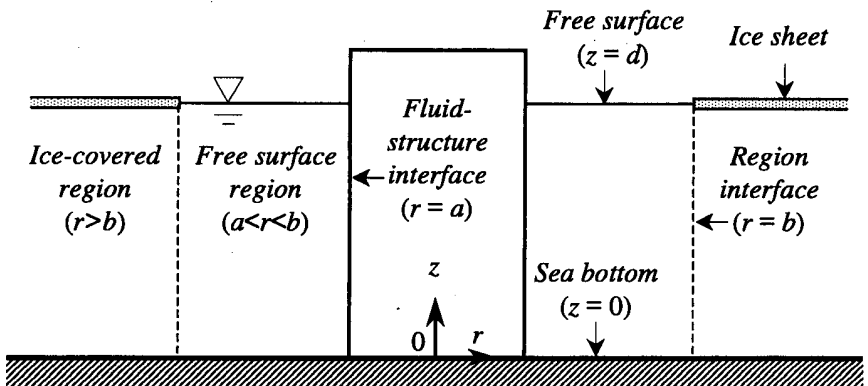

Fig. 2 Domain division method 
式(3a-d)を満足する剛体境界の下部領域における速度ポテンシャ ルは次式で与えられる。

$$
\phi_{i}=\sum_{n=0}^{\infty}\left[F_{n 0}\left(\frac{b}{r}\right)^{n}+\sum_{s=1}^{\infty} F_{n s} \frac{K_{n}\left(l_{s} r\right)}{K_{n}\left(l_{s} b\right)} \cos l_{s} z\right] \cos n \theta,
$$

ここに, $F_{n 0}$ と $F_{n s}$ は未定係数, $l_{s}=s \pi / d(s=1,2,3 \cdots)$ である。 式(4)を式(2d)に代入し，両辺に $\cos k_{l} z$ を乗じ， $z$ に関して区間 $[0, d]$ で積分すると次式を得る。

$$
\sum_{l=1}^{\infty} b_{n l}\left(\widetilde{K}_{n l} D_{n l}+\widetilde{I}_{n l} E_{n l}\right)=-i \sigma \int_{0}^{d} W_{n}(z) \cos k_{l} z d z,
$$

$$
\text { ここに, }
$$

$$
\begin{aligned}
& b_{n l}=\frac{1}{4 k_{l}}\left(\sin 2 k_{l} d+2 k_{l} d\right), \\
& \widetilde{K}_{n l}=\frac{K_{n}^{\prime}\left(k_{l} a\right)}{K_{n}\left(k_{l} b\right)} k_{l}, \quad \widetilde{I}_{n l}=\frac{I_{n}^{\prime}\left(k_{l} a\right)}{I_{n}\left(k_{l} b\right)} k_{l},
\end{aligned}
$$

であり， $W_{n}(z)$ は円周方向フーリエ波数 $n$ の面外変位である。

式(4)を式(2d)に代入し，両辺に $\cosh k z$ を乗じ， $z$ に関して区間 $[0, d]$ で積分すると次式を得る。

$$
\left(\widetilde{J}_{n} B_{n 0}+\widetilde{Y}_{n} C_{n 0}\right) b_{n}=i \sigma \int_{0}^{d} W_{n}(z) \cosh k z d z,
$$

$$
\text { ここに, }
$$

$$
\begin{aligned}
& b_{n}=\frac{1}{4 k}(\sinh 2 k d+2 k d), \\
& \widetilde{J}_{n}=\frac{J_{n}^{\prime}(k a)}{J_{n}(k b)} k, \quad \widetilde{Y}_{n}=\frac{Y_{n}^{\prime}(k a)}{Y_{n}(k b)} k,
\end{aligned}
$$

である。

自由表面境界と剛体境界の各下部領域の接続条件は以下のように 与えられる。

$$
\begin{array}{ll}
\frac{\partial \phi_{f}}{\partial r}=\frac{\partial \phi_{i}}{\partial r} & : r=b, 0 \leq z \leq d, \\
\phi_{f}=\phi_{i} & : r=b, 0 \leq z \leq d,
\end{array}
$$

ここに, 式(11a)は速度ポテンシャルの半径方向微分の接続条件(物 理的には海水の運動の連続条件), 式(11b)は速度ポテンシャルの接続 条件（物理的には圧力の連続条件）である。

式(4)と式(6)を式(1la)に代入し, 両辺に $\cosh k z$ を乗じ, $z$ に関して 区間 $[0, d]$ で積分すると次式を得る。

$$
\left(\bar{J}_{n} B_{n 0}+\bar{Y}_{n} C_{n 0}\right) b_{n}=-d_{n} F_{n 0}+\sum_{s=1}^{\infty} S_{n s} \bar{K}_{n s} F_{n s}
$$

$$
\text { ここに, }
$$

$$
S_{n s}=\frac{k}{l_{s}^{2}+k^{2}} \sinh k d \cos s \pi, \quad d_{n}=\frac{n}{b k} \sinh k d,
$$

$$
\bar{J}_{n}=\frac{J_{n}^{\prime}(k b)}{J_{n}(k b)} k, \quad \bar{Y}_{n}=\frac{Y_{n}^{\prime}(k b)}{Y_{n}(k b)} k, \quad \bar{K}_{n s}=\frac{K_{n}^{\prime}\left(l_{s} b\right)}{K_{n}\left(l_{s} b\right)} l_{s}, \quad(13 c, \mathrm{~d}, \mathrm{e})
$$
である。

式(4)と式(6)を式(11a)に代入し，両辺に $\cos k_{l} z$ を乗じ， $z$ に関して 区間 $[0, d]$ で積分すると次式を得る。

$$
\left(\bar{K}_{n l} D_{n l}+\bar{I}_{n l} E_{n l}\right) b_{n l}=-d_{n l} F_{n 0}+\sum_{s=1}^{\infty} S_{n s} \bar{K}_{n s} F_{n s},
$$
ここに

$$
S_{n s l}=\frac{k_{l}}{k_{l}^{2}-l_{s}^{2}} \sin k_{l} d \cos s \pi, \quad d_{n l}=\frac{n}{b k_{l}} \sin k_{l} d,
$$

$$
\bar{K}_{n l}=\frac{K_{n}^{\prime}\left(k_{l} b\right)}{K_{n}\left(k_{l} b\right)} k_{l}, \quad \bar{I}_{n l}=\frac{I_{n}^{\prime}\left(k_{l} b\right)}{I_{n}\left(k_{l} b\right)} k_{l},
$$

$(15 c, d)$

である。

式(4)と式(6)を式(11b)に代入し， $z$ に関して区間 $[0, d]$ で積分する と次式を得る。

$$
\left(B_{n 0}+C_{n 0}\right) f_{n}+\sum_{l=1}^{\infty}\left(D_{n l}+E_{n l}\right) f_{n l}=d F_{n 0},
$$

ここに

$$
f_{n}=\frac{1}{k} \sinh k d, f_{n l}=\frac{1}{k_{l}} \sin k_{l} d,
$$

である。

式(4)と式(6)を式(11b)に代入し, 雨辺に $\cos l_{s} z$ を乗じ, $z$ に関して区 間 $[0, d]$ で積分すると次式を得る。

$$
\left(B_{n 0}+C_{n 0}\right) S_{n s}+\sum_{l=1}^{\infty}\left(D_{n l}+E_{n l}\right) S_{n s t}=\frac{d}{2} F_{n s .}
$$

式(7), (9), (12), (14), (16), (18)は未定係数 $B_{n 0}, C_{n 0}, D_{n l}, E_{n l}(l=1,2, \cdots)$, $F_{n s}(s=0,1,2 \cdots)$ に関する無限個の連立方程式を構成する。実際に は有限個の連立方程式を解き未定係数を決定する。このとき, 級数 項の数はともに 20 とした。

\section{5. 自由振動解析}

地震動による荷重項, すなわち剛体運動による慣性力と動水圧成 分を 0 と扔き, Rayleigh-Ritz 法によりウェットモード自由振動解 析を定式化する。水平地震動のときは梁モードのみが励起されるの で円周方向フーリ工波数は $n=1$ のみを考之る。中空円筒構造物の 梁モードの弾性変形を以下の変位の 3 成分で表す9)。

$$
\begin{aligned}
& u=\sum_{j=1}^{N} U_{m 1 j} g_{j}(z) \cos \theta \exp \left(i \omega_{m 1} t\right), \\
& v=\sum_{j=1}^{N} V_{m 1 j} f_{j}(z) \sin \theta \exp \left(i \omega_{m 1} t\right), \\
& w=\sum_{j=1}^{N} W_{m 1 j} f_{j}(z) \cos \theta \exp \left(i \omega_{m 1} t\right),
\end{aligned}
$$

ここに, $u, v$, および $w$ はそれぞれ軸方向, 円周方向，および半 径方向変位成分, $N$ は既知関数の重ね合わせ数, $\omega_{m 1}$ は $m 1$ 次固有円 振動数, $g_{j}(z)$ と $f_{j}(z)$ はそれぞれ空中における片持梁の軸方向振動 と曲げ振動の $j$ 次正規関数である。

一般化座標として $U_{m 1 j}(t)=U_{m 1 j} \exp \left(i \omega_{m 1} t\right), V_{m 1 j}(t)=V_{m 1 j} \exp$ $\left(i \omega_{m 1} t\right), W_{m 1 j}(t)=W_{m 1 j} \exp \left(i \omega_{m 1} t\right)$ を用いると, 中空円筒構造物の. 運動は以下のラグランジェ方程式に支配される。

$$
\frac{d}{d t}\left(\frac{\partial T}{\partial \dot{U}_{m 1 j}}\right)-\frac{\partial T}{\partial U_{m 1 j}}+\frac{\partial S}{\partial U_{m 1 j}}=0,
$$

$$
\frac{d}{d t}\left(\frac{\partial T}{\partial \dot{V}_{m 1 j}}\right)-\frac{\partial T}{\partial V_{m 1 j}}+\frac{\partial S}{\partial V_{m 1 j}}=0,
$$

$\frac{d}{d t}\left(\frac{\partial T}{\partial \dot{W}_{m 1 j}}\right)-\frac{\partial T}{\partial W_{m 1 j}}+\frac{\partial S}{\partial W_{m 1 j}}=Q_{m 1 j}$,

ここに，SとTはそれぞれ円筒シェルのUずみエネルギーと運 動エネルギーである10)。

式(20c)の右辺の $Q_{m 1 j}$ は一般化力であり次式で与えられる。

$$
Q_{m 1 j}=\int_{0}^{l} \int_{0}^{2 \pi} p \cdot f_{j}(z) \cos \theta a d \theta d z
$$

ここに, 
式(19a-c)を式(20a-c)に代入し, 正規関数の直交性を利用すると, 静稳 な水海域で自由振動する構造物の運動方程式が以下のマトリクス式 として得られる。

$\left[[K]-\Delta\left([M]+\left[M_{W}\right]\right)\right]\{\delta\}=0$

(22)

ここに, $[K],[M]$, および $\left[M_{W}\right]$ は構造物の成性マトリクス $(3 N \times$ $3 N)$ ，質量マトリクス $(3 N \times 3 N)$ ，および構造物と海水の相互作用に よる付加質量マトリクス $(3 N \times 3 N),\{\delta\}=\{U|V| W\}^{T}$ は仮定モード 振幅べクトル $(3 N \times 1) て ゙,\{U\},\{V\}$, および $\{W\}$ はそれぞれ $U_{m 1 j}, V_{m 1 j}$, および $W_{m 1 j}$ を成分とするべクトル $(N \times 1), \Delta=\rho_{s} \omega_{m 1}^{2}$ $\left(1-\mu^{2}\right) a^{2} / E$ は振動数パラメー夕, $E$ は構造物のヤング係数, $\mu$ は ポアソン比， $\rho_{s}$ は質量密度である。

式(22)の振動数方程式は次式で与えられる。

$\left|[K]-\Delta\left([M]+\left[M_{W}\right]\right)\right|=0$

上式を解くことによりウェットモード振動数とモード形が求まる。

\section{6. 地震応答解析}

ウェットモード特性に関するモード合成法により水平地震動に対 する応答解析を定式化する。中空円筒構造物の軸方向，円周方向， および半径方向変位成分はそれぞれ以下のように与えられる。

$$
\begin{aligned}
& u=\sum_{m=1}^{\infty} u_{m 1}(z) \cos \theta q_{m 1}(t) \\
& v=\sum_{m=1}^{\infty} v_{m 1}(z) \sin \theta q_{m 1}(t) \\
& w=\sum_{m=1}^{\infty} w_{m 1}(z) \cos \theta q_{m 1}(t)
\end{aligned}
$$

ここに， $u_{m 1}(z), v_{m 1}(z)$ および $w_{m 1}(z)$ はそれぞれ $u, v$ ，およ び $w$ の $m 1$ 次軸方向関数, $q_{m 1}(t)$ は $m 1$ 次一般化座標である。

地震時の構造物の応答は以下のラグランジェ方程式に支配され る。

$$
\frac{d}{d t}\left(\frac{\partial T}{\partial \dot{q}_{m 1}}\right)-\frac{\partial T}{\partial q_{m 1}}+\frac{\partial S}{\partial q_{m 1}}=Q_{D m 1}+Q_{A m 1}
$$

ここに, $Q_{D m 1}$ は構造物の材料減衰に関する $m 1$ 次一般化減衰力, $Q_{A m 1}$ は $m 1$ 次の一般化力であり次式で与えられる。

$$
\begin{aligned}
& Q_{A m 1}=\int_{0}^{l} \int_{0}^{2 \pi}\left\{p_{z} u_{m 1}(z) \cos \theta+p_{\theta} v_{m 1}(z) \sin \theta\right. \\
&\left.+p_{r} w_{m 1}(z) \cos \theta\right\} a d \theta d z \\
& \text { ここに, } p_{z}=0, \\
& \text { - } p_{\theta}=-\rho_{s} h \sin \theta \cdot \ddot{U}_{g}, \\
& p_{r}=\rho_{s} h \cos \theta \cdot \ddot{U}_{g}+p_{R}+p_{E},
\end{aligned}
$$

であり， $p_{R}$ と $p_{E}$ はそれぞれ構造物の剛体運動と弾性変形による動 水圧成分である。

式(24a-c)を式(25)と(26)に代入し,ウェットモ一ド形の直交性を利用す ると以下のモーダル運動方程式が得られる ${ }^{11) 。 ~}$

$$
\left(M_{m 1}+M_{m 1}^{*}\right) \ddot{q}_{m 1}(t)+\left(C_{m 1}+C_{m 1}^{*}\right) \dot{q}_{m 1}(t)+K_{m 1} q_{m 1}(t)=Q_{m 1}(t)
$$

ここに, $M_{m 1}, C_{m 1}$, および $K_{m 1}$ はそれぞれ構造物の $m 1$ 次一般化 質量, 一般化減衰, および一般化剛性, $M_{m 1}^{*}$ と $C_{m 1}^{*}$ はそれぞれ構造物 と海水との相互作用による $m 1$ 次一般化付加質量と一般化付加減 衰， $Q_{m 1}(t)$ は $m 1$ 次一般化力であり次式で与えられる。

$$
\begin{aligned}
Q_{m 1}(t)=\rho_{s} h \pi a \int_{0}^{l}\{ & \left.-v_{m 1}(z)+w_{m 1}(z)\right\} d z \cdot \ddot{U}_{g}(t) \\
& +\int_{0}^{d} \int_{0}^{2 \pi} p_{R} w_{m 1}(z) \cos \theta a d \theta d z
\end{aligned}
$$

水平地盤加速度の定常部のパワースペクトル密度関数は次式の修 正金井・田治見式で与えられる ${ }^{12)}$ 。

$$
\begin{aligned}
& S_{\ddot{U}_{g} \ddot{U}_{g}}(\sigma)=S_{0}\left[\frac{1+4 \xi_{g}^{2}\left(\sigma / \omega_{g}\right)^{2}}{\left\{1-\left(\sigma / \omega_{g}\right)^{2}\right\}^{2}+4 \xi_{g}^{2}\left(\sigma / \omega_{g}\right)^{2}}\right] \\
& \quad \cdot\left[\frac{\left(\sigma / \omega_{k}\right)^{4}}{\left\{1-\left(\sigma / \omega_{k}\right)^{2}\right\}^{2}+4 \xi_{k}^{2}\left(\sigma / \omega_{k}\right)^{2}}\right] \quad:-\infty<\sigma<+\infty \quad \text { (30) }
\end{aligned}
$$

ここに，右辺の 1 番目の大カッコは金井・田治見のローパスフィ ル夕， 2 番目の大カッコは Clough-Penzienのハイパスフィルタで ある。また, $S_{0}$ はパワースペクトル強度, $\omega_{g}$ と $\xi_{g}$ はローパスフィ ルタのパラメータ， $\omega_{k}$ と $\xi_{k}$ はハイパスフィルタのパラメータであ る。

定常ランダム応答解析に基づき，構造物の各变位成分の二乗平均 值は以下のように表せる。

$$
\begin{aligned}
& \bar{u}^{2}=\sum_{m=1}^{\infty} u_{m 1}^{2}(z) \cos ^{2} \theta \bar{q}_{m 1}^{2} \\
& \bar{v}^{2}=\sum_{m=1}^{\infty} v_{m 1}^{2}(z) \sin ^{2} \theta \bar{q}_{m 1}^{2} \\
& \bar{w}^{2}=\sum_{m=1}^{\infty} w_{m 1}^{2}(z) \cos ^{2} \theta \bar{q}_{m 1}^{2}
\end{aligned}
$$

ここに， $\bar{q}_{m 1}^{2}$ は $m 1$ 次の一般化座標の分散である。加速度成分の 二乗平均值は $\bar{q}_{m 1}^{2}$ を $\stackrel{-}{q}_{m 1}^{2}$ に置き換えることにより求まる。

\section{7. 数值結果と検討}

構造物一海水間隙の存在による地震時動水圧の消散効果とその流 力弾性挙動への影響を検討するために数值例題を示す。構造物の形 状寸法は, $l=80 \mathrm{~m}, a=20 \mathrm{~m}, h=0.2 \mathrm{~m}$ とする。構造物の材料定数 は, $E=2.0 \times 10^{11} \mathrm{~N} / \mathrm{m}^{2}, \mu=0.3, \rho_{s}=8.0 \times 10^{3} \mathrm{~kg} / \mathrm{m}^{3}$ とする。構造 物一海水間隙の幅として $b-a=0,1,5,10,20,30 \mathrm{~m}$ および $\infty を$ 考 える。すなわち, 間隙がなく海水が無限に広がっている状態と海面 の全てが自由表面である状態を両極限として, 間隙の幅を 7 ケース 設定する。海水下の海水の質量密度は $\rho_{w}=1.02 \times 10^{3} \mathrm{~kg} / \mathrm{m}^{3}$ とする。

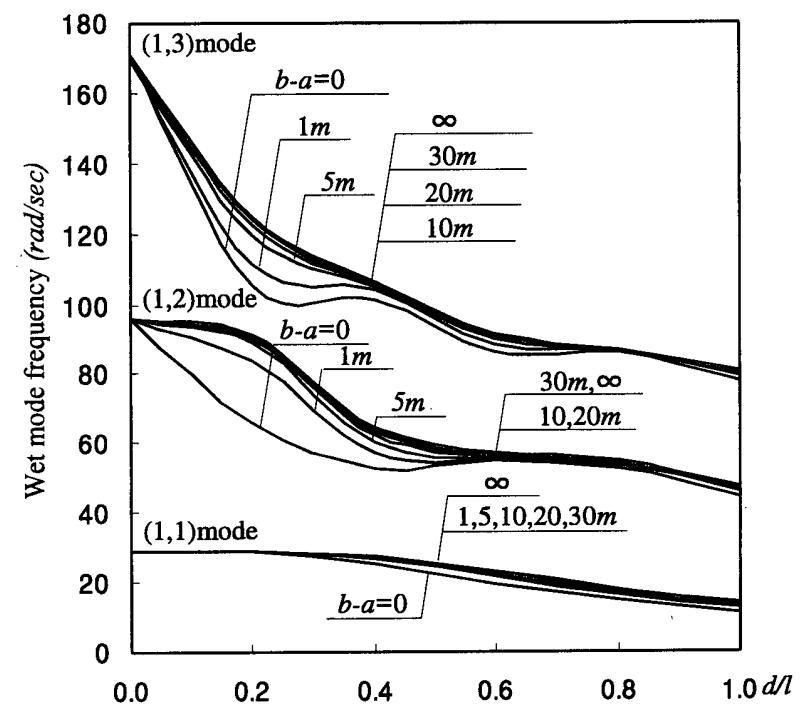

Fig. 3 Change in wet mode frequencies due to the width of structure-ice gap 

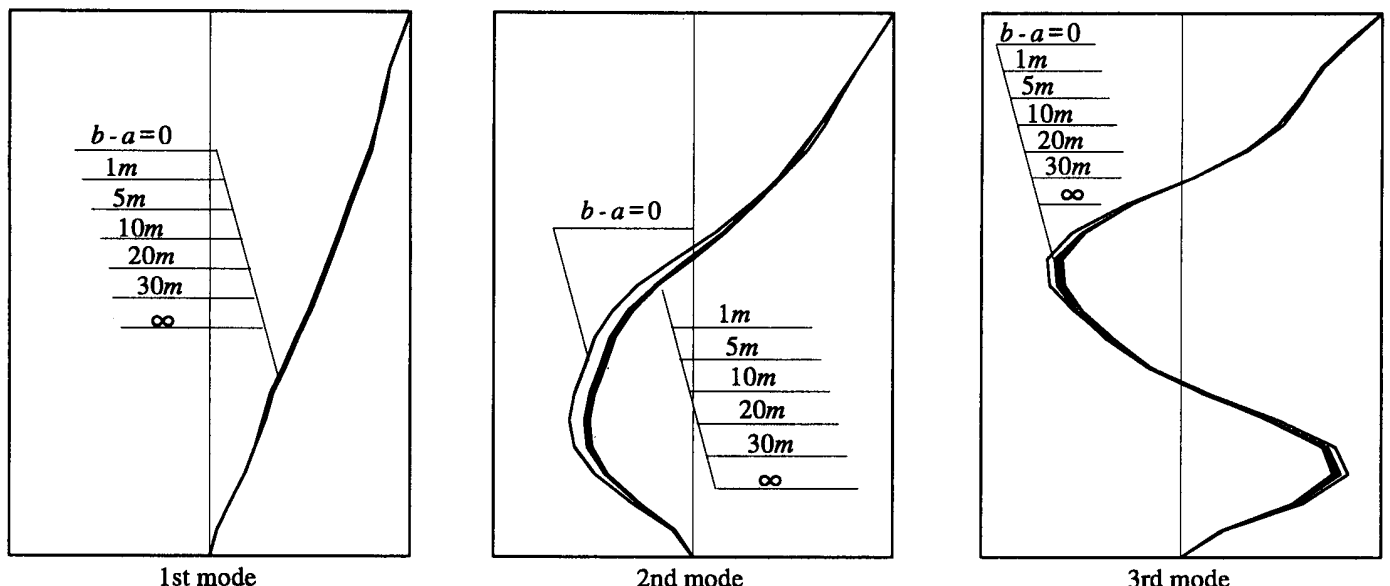

Fig. 4 Change in wet mode shapes due to the width of structure-ice gap

式(19)の級数の項数は $N=7$ とする。式(30)のパワースペクトル密度関 数のパラメー夕值は, 硬質地盤として $\omega_{g}=15.6 \mathrm{rad} / \mathrm{sec}, \xi_{g}=0.6$, $\omega_{k}=1.0 \mathrm{rad} / \mathrm{sec}, \xi_{k}=0.6$, スペクトル強度は El Centro $1940 \mathrm{NS}$ に対応する $S_{0}=4.8 \times 10^{-3} \mathrm{~m}^{2} / \mathrm{sec}^{3} \mathrm{rad}$ とする12)

ウェットモード自由振動解析を行い，構造物一海永間隙の幅が ウェットモード特性に与える影響を検討する。Fig. 3 に, 間隙の幅を パラメータとして，梁モード $(n=1)$ のウェットモード振動数の設 置水深による変化を軸方向モード次数 $m=1,2,3$ に対して示す。間

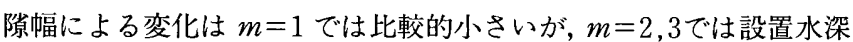
が浅いと差が大きく，深いと差が小さい。間隙幅の増加とともに動 水圧の消散効果により付加質量が減少し，ウェットモード振動数は 増加している。各モードとも間隙幅が構造物の半径程度になると無 氷状態の場合の値に収束する傾向を示す。

Fig. 4 に, 間隙幅をパラメータとして, 地震応答解析で用いる設置 水樑 $d / l=0.8$ における梁モ一ドのウェットモード形の変化を軸方 向モード次数 $m=1,2,3$ に对して示す。Fig. 3 の $d / l=0.8$ における ウェットモード振動数の差が小さいのに対応して，間隙の幅がモー ド形に与える影響も極めて小さい。

水平地震動を受けたときの地震応答解析を行う。設置水深は $d / l=0.8$ とする。Fig. 5 に, 水平地震動の加速度パワースペクトル と全水状態および無水状態の場合の梁モードのウェットモード振動 数の関係を示す。両状態とも $m=1$ のウェットモード振動数は水平 地動のスペクトルの主要領域に入っているが, $m=2$ のウェット モード振動数はスペクトルの主要領域から大きく離れている。

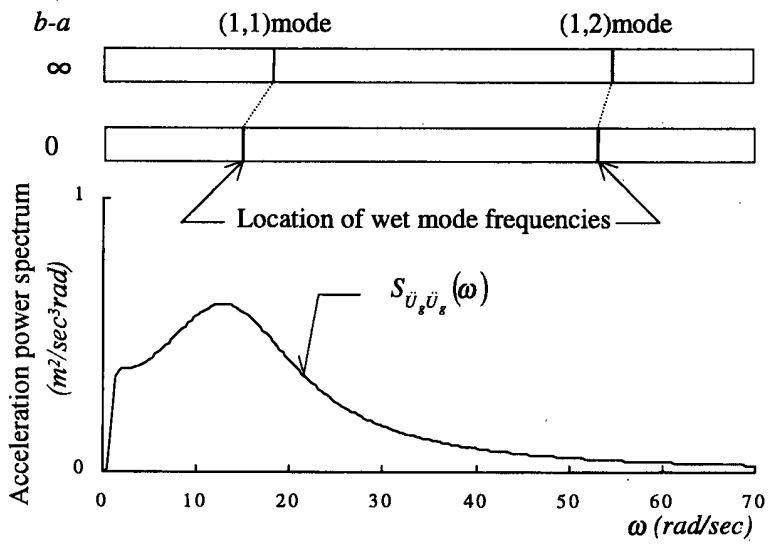

Fig. 5 The location of wet mode frequencies with and without structureice gap in the frequency domain
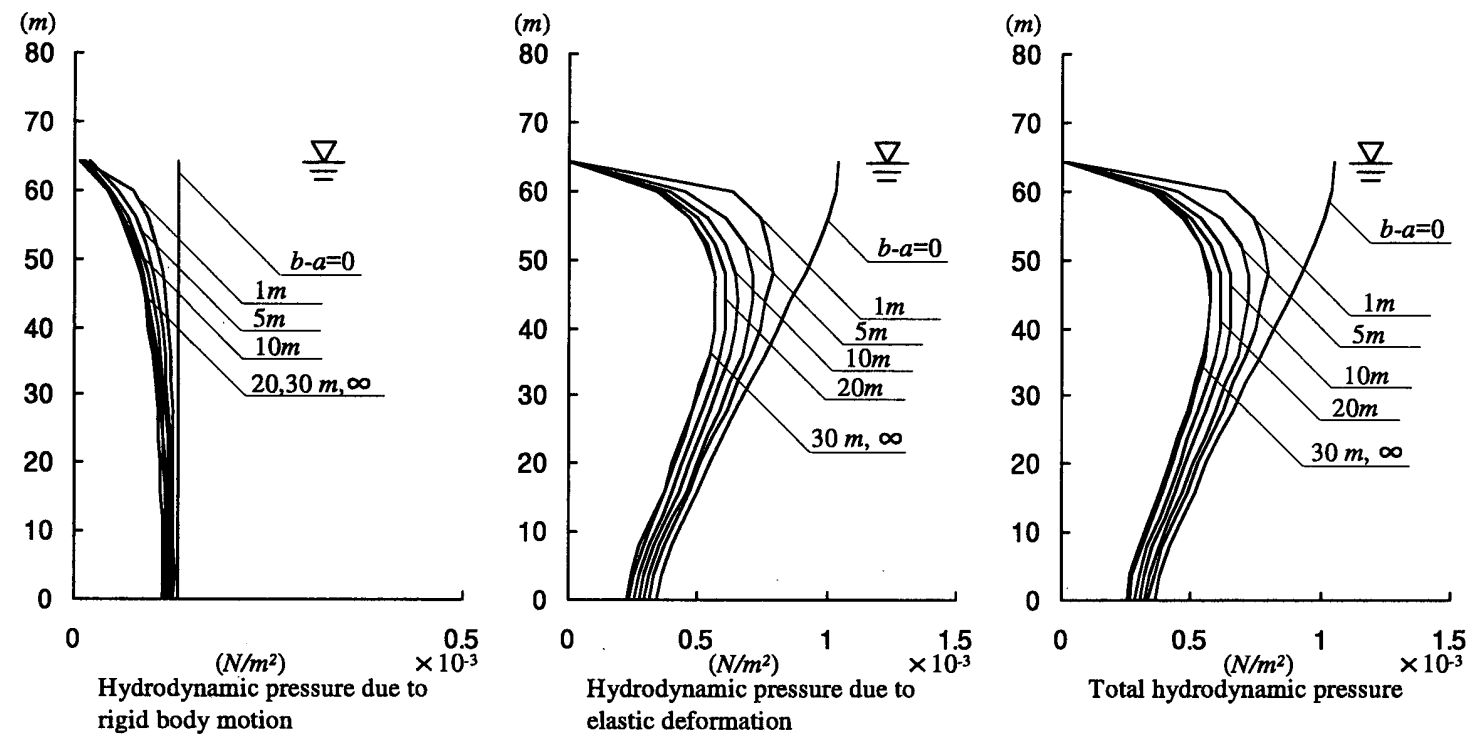

Fig. 6 Change in hydrodynamic pressure distributions due to the width of structure-ice gap 
Fig. 6 に, 水平地震動を受けたときの間 隙幅による動水圧分布の変化を示す。構造 物の剛体運動による動水圧成分, 弾性変形 による動水圧成分，および両者の和として の全動水圧を $\mathrm{rms}$ 値として求めた。岡体運 動による動水圧成分は無限水盤 $(b-a=0)$ では深さ方向に一定の值となるが, 間吵幅 が大きくなるにつれて海面付近の動水圧が 減少する。弾性変形による動水圧成分は間 隙幅が大きくなるにつれ海底から海面まで の全領域で減少する。全動水圧に占める割 合は弾性変形による動水圧成分が剛体運動 による動水圧成分に比べて支配的である。 間隙幅が構造物の直径程度になると無水状 態の場合の動水圧に収束することが確認で きる。

Fig. 7 に, 水平地震動を受けたときの間隙幅による相対変位と相 対加速度の $\mathrm{rms}$ 応答の変化を示す。本例題では, 間隙幅が大きくな るにつれて $m=1$ のウェットモード振動数が水平地震動の加速度パ ワースペクトルの主要領域から遠去かっており, 変位応答は徐々に 減少している。しかし，相対加速度は 2 次モードの寄与等により規 則性は見られず，かつ間陌幅にはそれほど敏感ではない。

\section{8. 結 び}

水海域に建設される固定式構造物の耐震設計においては，周囲の 水盤の影響を地震荷重の増幅効果と構造物と水盤の相互作用効果に 分け，それぞれを構造物と水盤の幾何学的特性と材料特性に関する パラメータの関数として定量的に評価することが望まれる。本研究 は, 前者の地震荷重の増幅効果に関して数理モデルを用いて検討し たものであるが, 特に著者らの既往の研究では無視してきた構造物 一海水間吵による動水圧の消散効果に注目している。

地震時の流力弾性挙動を考虑して，承盤を剛体境界，間隙を自由 表面境界とする混合境界値問題を解き, 構造物一海水間隙の幅によ るウェットモード特性と水平地震動を受けるときの動水圧分布およ び流力弾性応答への影響を検討した。本研究の範囲内で得られた知 見を以下に要約する。

1）構造物一海水間䊗の幅が大きくなるにつれ, 動水圧の消散効果 は大きくなり付加質量が減少する。このため, ウェットモード振 動数は徐々に増加し，間隙幅が構造物の半径程度になるとほぼ無 水状態の場合の結果に収束寸る。

2）構造物の高さに比べて設置水深が十分に媣い場合，構造物一海 氷間隙の幅はウェットモード形にほとんど影響を与えない。

3 ）水平地震動に対し, 構造物の剛体運動による動水圧成分は無限 水盤では海底から海面まで一定の值で分布するが，構造物一海水 間隙の幅が大きくなるにつれて海面近傍での減少が顕著になる。 弾性変形による動水圧成分は間隙幅が大きくなるにつれて深さ方 向の全領域で減少する。両動水圧成分とも間隙幅が構造物の直径 程度になると無水状態の場合の值に収束する。弾性変形による動 水圧成分は剛体運動による動水圧成分よりはるかに大きい。

4 ）水平地震動に対し，剛体運動による動水圧成分は構造物一海水
間隙の幅の増加とともに減少し付加入力は減少する。一方, 間隙 が大きくなると弾性変形による動水圧成分も減少しウェットモ一 ド振動数を堌加させる。このため, 地震動の周波数特性に依存して 応答を増幅させる場合もあれば減少させる場合もある。間隙幅の影 響は変位応答には明確に現れるが, 加速度応答への影響は小さい。 既報》では，構造物周辺の海水による地震荷重の増幅効果を氷盤 の幅の関数として評価した。本報では，構造物一海水間隙による地 震荷重の低減効果を間吵幅の関数として評価した。相反する効果を 検討した両結果を統合することにより，水海構造物の耐震設計にお ける地震荷重を適切に設定する根拠が与えられると考える。

\section{参考文献}

1) Croteau, P.: Dynamic Interactions Between Floating Ice and Offshore Structures, Report No. UCB/EERC-83/06, Earthquake Engineering Research Center, Univ. of California, 1983.

2）安達 洋, 中西三和ほか：水海域に扔ける構造物の地震応答に関する研究 (その $1 \sim 17$ ), 日本建築学会大会学術講演梗概集, 1987 96

3）清川哲志, 黒川 明, 川口靖博：水海構造物の地震時動水圧解析, 第14回 海洋工学シンポジウム論文集, 日本造船学会, pp.187-194, 1998

4）森田知志, 西垣 亮, 小林 浩: 水盤に閉ざされた重力式海洋構造物回り の地震時動水压の特性, 海洋開発論文集, 土木学会, Vol. 15, pp.571-576, 1999

5）濱本卓司, 大西弘亮, 井上昌志, 田中弥寿雄：氷海域における中筒シェル の地震応答, 構造工学論文集, 日本建築学会, Vol. 46B, pp.135-140, 2000

6) Hamamoto, T., Inoue, M., Tanaka, Y. : Seismic Analysis of Vertical Cylindrical Towers in Ice-Covered Seas, Proc. of the $12^{\text {th }}$ WCEE, Paper No. 1071, 2000.

7）濱本卓司, 大西弘亮, 井上昌士：有限な薄水盤に囲まれた固定式中空円筒 構造物の地震流力弾性解析, 日本建築学会構造系論文集, 第 542 号, pp. 203-210, 2001.4

8) Kobayashi, H., Kawaguchi, H.: Evaluation of Seismic Loads on Offshore Structure in Ice-Covered Waters, Proc. of the $10^{\text {th }}$ Int. Offshore and Polar Engrg. Conf., Vol. 1, pp.674-678, 2000.

9）濱本卓司, 田中彌壽雄：固定式海洋円筒シェルの動的解析 その 1 : 固有 振動解析, 日本建築学会論文報告集, 第291号, pp.129-141, 1980.5

10) Novozhilov, V.V.: Thin Shell Theory, Wolters-Noordhoff Pub., 1970.

11）濱本卓司, 田中彌壽雄：固定式海洋円筒シェルの動的解析 その 3 : 地震 応答解析，日本建築学会論文報告集，第303号，pp.141-154，1981.5

12) Clough, R.W., Penzien, J.: Dynamics of Structures, McGraw-Hill, 1975.

(2000年12月 27 日原稿受理, 2001 年 3 月 26 日採用決定） 